\title{
Inclusion of psyllium in milk replacer for neonatal calves. 2. Effects on volatile fatty acid concentrations, microbial populations, and gastrointestinal tract size ${ }^{1}$
}

\author{
S. J. Cannon, ${ }^{* 2}$ G. C. Fahey Jr., ${ }^{*}$ L. L. Pope, ${ }^{* 3}$ L. L. Bauer, ${ }^{*}$ R. L. Wallace,† B. L. Miller,‡ and J. K. Drackley ${ }^{* 4}$ \\ *Department of Animal Sciences, and \\ †Department of Veterinary Clinical Medicine, University of Illinois, Urbana 61801 \\ łLand O’Lakes Animal Milk Products, Arden Hills, MN 55126
}

\begin{abstract}
Fermentable fibers such as psyllium increase volatile fatty acid (VFA) concentrations in the lower digestive tract and increase the gastrointestinal tract (GIT) mass of many mammals. We reasoned that psyllium inclusion in milk replacer might produce similar effects in neonatal dairy calves, which could lead to improved growth and health. Male Holstein calves were fed a milk replacer $(22 \%$ crude protein, $20 \%$ fat) either without or with psyllium (1.1\% of dry matter, DM) from $2 \mathrm{~d}$ through $28 \mathrm{~d}$ of age. Milk replacer was reconstituted to $12.5 \% \mathrm{DM}$ and fed at $12 \%$ of calf body weight, adjusted weekly. Water was offered ad libitum but no starter was fed. Three calves per treatment were harvested weekly to sample digesta from the reticulo-rumen, abomasum, jejunum, proximal colon, and distal colon, and to determine length and mass of GIT components. Psyllium in milk replacer increased the proportion of butyrate in reticulo-rumen contents from 2.4 to $3.2 \%$ of total but did not affect total VFA concentrations. Total VFA concentrations were very low in the jejunum but psyllium tended to increase total VFA, acetate, and valerate concentrations; valerate accounted for 15.9 and $16.7 \%$ of total VFA (molar basis) for control and psyllium calves, respectively. Psyllium increased total VFA concentrations in the proximal and distal colon by 104.4 and $45.6 \%$, respectively, but had little effect on the profile of VFA. Psyllium in milk replacer increased populations of bifidobacteria (from 9.7 to $10.3 \log _{10}$ $\mathrm{cfu} / \mathrm{g}$ of DM) and lactobacilli (from 8.2 to $9.4 \log _{10}$ $\mathrm{cfu} / \mathrm{g}$ of DM) in the reticulo-rumen, but did not affect populations in jejunum or colon. Calves fed psyllium
\end{abstract}

\footnotetext{
Received January 12, 2010.

Accepted May 17, 2010.

${ }^{1}$ Supported by state and federal funds appropriated to the Illinois Agricultural Experiment Station and by Land O'Lakes Animal Milk Products, Arden Hills MN.

${ }^{2}$ Current address: Standard Dairy Consultants, 3303 N. Casaloma Dr., Appleton, WI 54913.

${ }^{3}$ Current address: 2204 Newport Way NW, Issaquah, WA 98027.

${ }^{4}$ Corresponding author: drackley@illinois.edu
}

had $12.0 \%$ greater total GIT mass and $9.4 \%$ greater GIT as a percentage of body weight. Psyllium tended to increase mass of the reticulo-rumen and significantly increased mass of duodenum (34.2\%), jejunum (14.5\%), and colon (14.6\%). Density of intestinal tissues from calves fed psyllium-supplemented milk replacer was $25.9 \%$ greater in the jejunum and $25.3 \%$ greater in the ileum, and tended to be greater in duodenum and colon than tissue from control calves. Supplementation of psyllium to milk replacer increased fermentation in the colon, mass of the total GIT, and populations of bifidobacteria and lactobacilli in the reticulo-rumen.

Key words: psyllium, dairy calf, gastrointestinal mass, fermentation

\section{INTRODUCTION}

Neonatal dairy calves are subject to development of scours (diarrhea) and other gastrointestinal upsets, which contribute to high rates of morbidity and mortality (National Animal Health Monitoring System, 2007). Fermentable dietary fibers may help improve gut health via several physiological mechanisms (Mälkki, 2001). Inclusion of soluble fibers in the diet improved gut barrier function in rabbits (Gómez-Conde et al., 2007) and decreased severity of an experimental Salmonella typhimurium infection in piglets (Correa-Matos et al., 2003). Psyllium, a viscous, moderately fermentable, nonstarch polysaccharide, ameliorated the secretory diarrhea induced by enterotoxigenic Escherichia coli in piglets (Hayden et al., 1998).

Dietary psyllium has been studied in humans and other species for its potential effects on digestive function, rate of passage, nutrient absorption, intestinal morphology, and intermediary metabolism ( $\mathrm{Yu}$ et al., 2009). Psyllium is fermented by fecal microbiota from humans (Campbell and Fahey, 1997), monkeys (Costa et al., 1989a), dogs (Swanson et al., 2001), and rats (Edwards et al., 1992). Increased fermentation of psyllium in the lower tract of rats results in greater concentrations of VFA, which in turn increase gastrointestinal tract (GIT) mass (Leng-Peschlow, 1991; Edwards et 
al., 1992; Schneeman and Richter, 1993). The VFA, particularly butyrate, act to increase mass and function of intestinal tissues by serving as metabolic substrates, by directly stimulating gene transcription for certain proteins such as nutrient transporters, and by stimulating release of the gut trophic hormone glucagon-like peptide-2 from enteroendocrine L cells (Tappenden et al., 2003).

The GIT microflora of milk-fed calves is dominated by bifidobacteria and lactobacilli, similar to that of the GIT of milk-fed infants (Vlková et al., 2006). These genera can ferment many nonstarch polysaccharides and inhibit gut colonization by pathogenic bacteria (Servin, 2004). A larger GIT with a more stable population of desirable bacterial species and improved barrier function might improve growth and health in young dairy calves. Although psyllium has been investigated as an adjunct therapy for diarrhea (Naylor and Liebel, 1995; Cebra et al., 1998), little is known about the effects of continuous supplementation of psyllium to the diet of young calves.

Previously we reported that addition of psyllium to milk replacer increased viscosity of digesta in the abomasum and colon, decreased DM content of colonic digesta and feces, and decreased the passage rate of digesta in the total digestive tract of healthy neonatal calves (Cannon et al., 2010). As part of that study, the objective of the research reported here was to determine the effects of inclusion of psyllium in milk replacer on VFA concentrations and microbial populations throughout the GIT, as well as on weight, length, and density of GIT tissues in neonatal dairy calves. Our hypothesis was that psyllium would be fermented in the lower small intestine and colon with a resultant increase in concentrations of VFA in the lower digestive tract. Furthermore, we predicted that the increased VFA would stimulate greater mass and density of the GIT tissues.

\section{MATERIALS AND METHODS}

\section{Animals and Feeding}

All procedures were approved by the University of Illinois Institutional Animal Care and Use Committee (protocol number 04083). Details of selection of calves, general husbandry, and dietary management were presented previously (Cannon et al., 2010). Briefly, the study was conducted with 2 blocks of 12 and 22 male calves purchased from a local commercial dairy at less than $36 \mathrm{~h}$ of age. Healthy calves were transported to the University of Illinois Dairy Nutrition Field Laboratory (Urbana) and housed in individual hutches
(Calf-Tel, Hampel Corp., Germantown, WI) on crushed limestone. No bedding was used, to minimize ingestion of organic bedding material that might confound treatment inferences.

Calves were blocked by pairs based upon birth date, $\mathrm{BW}$, and total protein concentration in plasma and then randomly assigned within pair to each of the dietary treatments. These pairs of calves were then randomly assigned to harvest week. Treatments were milk replacers (Land O'Lakes Animal Milk Products Co., Arden Hills, MN) without (control; CON) or with a $1.1 \%$ inclusion of psyllium (PSY). Psyllium was obtained from Kadam Exports Pvt. (Mehsana, India). The level of psyllium supplementation was selected based on previous unpublished experiments as the lowest amount that significantly improved growth, fecal scores, and starter intake (B. L. Miller, Land O'Lakes Animal Milk Products, Arden Hills, MN; unpublished data). Milk replacers were formulated to contain $22 \% \mathrm{CP}$ and $20 \%$ fat. Milk replacers contained only milk proteins and were not medicated. Although the diet formulation is proprietary, psyllium was added into the control formulation and so diluted all ingredients slightly. Calves were fed at 0600 and $1800 \mathrm{~h}$. Milk replacers were reconstituted to $12.5 \% \mathrm{DM}$ and fed at a rate of $12 \%$ of BW daily, adjusted weekly as calves grew. Water was available to calves for ad libitum consumption, with fresh warm water provided twice daily after each milk replacer feeding. No other feeds were offered.

\section{Collection of Samples}

Pairs of calves were harvested weekly for analysis as described by Cannon et al. (2010). Calves were not given their morning milk replacer before being euthanized. Calves were sedated by administration of Xylazine $\mathrm{HCl}$ intramuscularly $(50 \mathrm{mg} / \mathrm{mL}$; Fort Dodge Animal Health, Fort Dodge, IA) and then killed with an intravenous overdose of sodium pentobarbital (Fatal Plus, Veterinary Laboratories Inc., Lenexa, KS) followed by exsanguination.

When the calf was declared dead, the veterinarian opened the body cavity. The GIT was ligated at the caudal esophagus and rectum and removed as rapidly as possible without damaging the tract. To prevent movement of digesta between compartments, the different segments of the GIT were identified and ligated. The GIT was then divided into 3 portions: the stomach portion consisting of rumen, reticulum, omasum, and abomasum; the small intestine, consisting of duodenum, jejunum, and ileum; and the colon. Each portion was processed by a respective team of personnel for tissue and digesta collection. 


\section{Digesta Collection}

Individual aliquots of digesta from the rumen, jejunum, and colon were placed into preweighed Cary-Blair transport media containers (Meridian Diagnostics, Cincinnati, OH). The Cary-Blair medium allows for stabilization of anaerobic microorganisms before laboratory enumeration for lactobacilli, bifidobacteria, Clostridium perfringens, and E. coli.

For VFA sample collection, 1 to $5 \mathrm{~mL}$ of digesta was placed into a preweighed Nalgene bottle (Nalge Nunc International, Rochester, NY) containing $10 \mathrm{~mL}$ of $2 \mathrm{~N}$ $\mathrm{HCl}$. The bottle then was reweighed to determine the exact amount of digesta added. Samples were stored at $-20^{\circ} \mathrm{C}$ until analysis.

After all digesta had been removed from the GIT, each portion was rinsed. Wet weights and lengths were measured and recorded for calculation of GIT size and scale parameters.

\section{Microbial Analyses}

The procedure for enumeration of Bifidobacterium spp. was that of Muñoa and Pares (1988), utilizing Bifidobacteria agar (Difco Laboratories, Detroit, MI). Lactobacillus spp. were cultured on Rogosa SL agar (Difco Laboratories). Clostridium perfringens was cultured on Clostridia agar (Sigma-Aldrich, St. Louis, MO), utilizing the method from FDA (1992). Escherichia coli were cultured on EMB agar (Difco Laboratories).

When digesta samples arrived at the laboratory, serial dilutions $\left(10^{-1}\right.$ through $\left.10^{-8}\right)$ in anaerobic diluent were made from the Cary-Blair media containing digesta according to the methods of Bryant and Burkey (1953). Droplets of 5 appropriate dilutions were then inoculated onto their respective Petri dishes for each of the 4 agars to maximize counting precision of the microbial colonies. Each Petri dish received 7 droplets of $10 \mu \mathrm{L}$ each. After droplets had been adsorbed to the sterile agar, plates for bifidobacteria, lactobacilli, and $C$. perfringens were inverted and incubated anaerobically $\left(95 \% \mathrm{CO}_{2}\right.$ and $\left.5 \% \mathrm{H}_{2}\right)$ at $39^{\circ} \mathrm{C}$. Plates for E. coli were incubated aerobically at $37^{\circ} \mathrm{C}$. Colonies were counted (cfu/g of sample) after 24 to $48 \mathrm{~h}$ of incubation. Plates exhibiting 4 to $20 \mathrm{cfu}$ per droplet were counted and averaged. One colony-forming unit was defined as a distinct colony measuring at least $1 \mathrm{~mm}$ in diameter. Colony-forming units per gram sample (DM basis) were calculated as

$\mathrm{cfu} / \mathrm{g}=\frac{(\text { mean } \mathrm{cfu}) \times(\text { dilution }) \times(\text { diluent dilution })}{(\mathrm{g} \text { of sample, } \mathrm{DM} \text { basis }) \times(\mathrm{mL} \text { in droplet on plate })}$.

\section{VFA Analyses}

Samples of digesta collected from the rumen, abomasum, jejunum, proximal colon, and distal colon were prepared for analysis of VFA concentrations, using the methods of Erwin et al. (1961) with modifications. Briefly, an initial centrifugation $(500 \times g)$ of the samples was performed to remove particulate matter, using a Beckman centrifuge with a JA-14 rotor. Aliquots (4 $\mathrm{mL}$ ) of the samples acidified in $\mathrm{HCl}$ were mixed with 1.0 $\mathrm{mL}$ of $250 \mathrm{~g} / \mathrm{L} m$-phosphoric acid, precipitated at room temperature for $30 \mathrm{~min}$, and centrifuged at 20,000 $\times$ $g$. The supernatant was decanted and frozen overnight at $-20^{\circ} \mathrm{C}$ in microcentrifuge tubes. The supernatant was thawed and the microcentrifuge tubes were centrifuged at $13,000 \times g$ for 15 min using an Eppendorf 5804 centrifuge with an F-4S-30-11 rotor (Brinkmann Instruments, Westbury, NY). Samples were centrifuged with centrifugal filters (Centricon 3000 MC, Millipore, Billerica, MA) to remove remaining particulate matter. The supernatants were then placed in gas chromatography vials (SUN-SRI, Duluth, GA) that were capped and refrigerated until concentrations of VFA were determined.

Concentrations of VFA in the supernatants were determined by GLC. Briefly, concentrations of acetate, propionate, butyrate, isobutyrate, valerate, and isovalerate were determined using a Hewlett-Packard 5890A Series II gas chromatograph (Palo Alto, CA) fitted with a glass column $(180 \mathrm{~cm} \times 4 \mathrm{~mm}$ i.d. $)$ packed with $10 \%$ SP-1200/1\% $\mathrm{H}_{3} \mathrm{PO}_{4}$ on 80/100 mesh Chromosorb W AW (Supelco Inc., Bellefonte, PA). Nitrogen was the carrier gas with a flow rate of $75 \mathrm{~mL} / \mathrm{min}$. Oven temperature, detector temperature, and injector temperature were 125,175 , and $180^{\circ} \mathrm{C}$, respectively. Concentrations of VFA were corrected for quantities of VFA measured in reagent blank tubes analyzed concurrently.

\section{Statistical Analysis}

Statistical analyses were conducted as described previously (Cannon et al., 2010) utilizing the Proc Mixed procedure of SAS (version 9.1, SAS Institute Inc., Cary, $\mathrm{NC}$ ). The data were analyzed as a randomized complete block design, with block as a random effect. Effects of diet, age (i.e., week), and the interaction of diet and age were included in the model as fixed effects. Baseline calves were not included in the analysis, but baseline means and standard errors are shown for comparison. Significant differences were declared at $P<0.05$ and trends were declared at $P<0.10$. For interactions of diet and week where $P<0.10$, single degree of freedom contrasts were constructed to explore the interaction 
of diet with the linear, quadratic, and cubic effects of week. Where the interaction of diet and week was significant, means also were separated by using the PDIFF procedure in SAS.

\section{RESULTS AND DISCUSSION}

\section{VFA Concentrations and Profiles}

The concentration of total VFA in reticulo-ruminal contents did not differ significantly between treatments or among weeks (Table 1). The total VFA concentration for baseline calves was similar to that reported by Anderson et al. (1987a,b) for 1-wk-old calves consuming only whole milk. Concentrations during wk 1 to 4 , however, were considerably greater than values observed by Anderson et al. (1987a,b) for calves not consuming starter. Calves were not housed with organic bedding and were not offered starter, although rumen contents of 6 of the 14 calves fed PSY and 7 of the 13 calves fed CON had detectable grass or weeds that calves were able to reach through the wire pens surrounding the hutch opening. Amounts found in rumen contents were very small and did not greatly affect rumen VFA concentrations or profiles. Total VFA concentration in rumen contents did not differ between calves that had or did not have grass or weeds in the rumen for either $\mathrm{CON}$ (mean $\pm \mathrm{SD}, 43.7 \pm 11.4$ vs. $46.0 \pm 7.9 \mathrm{mmol} / \mathrm{L}$ ) or PSY groups $(53.5 \pm 12.9$ vs. $51.6 \pm 15.8 \mathrm{mmol} / \mathrm{L})$. Indeed, the highest total VFA concentration (130.7 $\mathrm{mmol} / \mathrm{L}$; excluded as an outlier because $>3 \mathrm{SD}$ greater than overall mean) was from a control calf that did not have detectable grass or weeds in rumen contents. Therefore, the VFA in the rumen presumably arose mainly from fermentation of limited amounts of milk replacer that leaked into the rumen via incomplete closure of the reticular groove. The VFA concentration in our study may have been larger because of the greater milk feeding rate ( $12 \%$ of BW, adjusted weekly) than in the Anderson et al. (1987a,b) study (8\% of birth BW).

The treatment $\times$ week interaction approached significance $(P<0.10)$ for concentrations of propionate and butyrate in the reticulo-rumen (Table 1). These trends were attributable to interaction of diet with the cubic effect of week, in which concentrations were higher for PSY calves in wk 1 but higher in CON calves during wk 2. Because of the small numbers of calves measured at each age, additional research would be necessary to determine whether these age-related changes were repeatable and of any significance to rumen development.

The profile of VFA in ruminal contents of baseline calves was similar to that reported in 1-wk-old calves fed only milk (Anderson et al., 1987a). Molar percentages of individual VFA did not vary significantly by treatment with the exception of butyrate (Table 1), which was greater $(P<0.05)$ for PSY calves than for CON calves. An interaction of treatment $x$ week also occurred for rumen butyrate percentages $(P<0.04)$, with butyrate percentage being higher in PSY except at wk 2. A tendency $(P<0.07)$ for interaction of diet and week was also detected for acetate percentage, which was attributable to an interaction of diet with the quadratic effect of week; means were greater for controls in wk 1 but less for controls in wk 2. The greater relative abundance of butyrate could be of interest because butyrate is the VFA most responsible for stimulation of rumen epithelial development (Heinrichs, 2005). The presence of the fermentable psyllium in any milk replacer entering the rumen of PSY calves may have led to a greater proportion of butyrate formation.

As expected, total VFA concentrations were low in the abomasum (Table 2), being only $2.3 \%$ of values in the rumen for baseline calves and only about $12 \%$ of mean ruminal concentrations thereafter. Presumably, the VFA present in the abomasum arose from ruminal outflow. No significant differences in concentrations were observed between dietary treatments (Table 2). A tendency for a treatment $\times$ week interaction existed for total VFA concentration and isobutyrate concentration, where concentrations were greater for PSY in wk 1 but greater for controls in wk 2 (diet $\times$ quadratic effect of week, $P<0.06)$. The molar percentage of isovalerate was greater and that of butyrate tended $(P=0.07)$ to be greater for PSY than for CON. Treatment $\times$ week interactions were significant for percentages of acetate and propionate in abomasal contents (Table 2). For acetate percentage, PSY calves were greater at wk 2 but $\mathrm{CON}$ calves were greater at wk 1 (diet $\times$ quadratic effect of week, $P<0.01$ ). In the case of propionate, PSY calves tended to be greater at wk 1 and 4 but not at wk 2 and 3 (diet $\times$ quadratic effect of week, $P<0.05$ ).

Concentrations of VFA were also very low in jejunal contents (Table 3), as predicted. Total VFA concentration in the jejunum of baseline calves was greater than in the abomasum, but thereafter concentrations were lower in the jejunum. Overall means for total VFA in the jejunum were about $3.7 \%$ of concentrations in the rumen. Calves fed PSY tended $(P<0.07)$ to exhibit greater total VFA and acetate concentrations than calves fed CON (Table 3), and concentrations generally decreased with age (Table 3). Greater VFA concentrations for calves fed PSY may indicate that bacteria within the lower jejunum were able to ferment a portion of the psyllium during its passage through the small intestine. The concentration of valerate was greater for PSY than for CON, and the treatment $x$ week interaction was significant; valerate was greater for PSY calves for all weeks except wk 4 . The molar 
Table 1. Least squares means and associated standard errors for weekly concentrations (mmol/L) and molar percentages (\%) of VFA in ruminal digesta from calves fed control milk replacer $(\mathrm{CON})$ or milk replacer supplemented with psyllium (PSY)

\begin{tabular}{|c|c|c|c|c|c|c|c|c|c|c|c|c|c|c|c|c|c|c|c|c|}
\hline \multirow[b]{2}{*}{ Variable } & \multicolumn{2}{|c|}{ Baseline $^{1}$} & \multicolumn{3}{|c|}{ Week 1} & \multicolumn{3}{|c|}{ Week 2} & \multicolumn{3}{|c|}{ Week 3} & \multicolumn{3}{|c|}{ Week 4} & \multicolumn{3}{|c|}{ Overall diet means } & \multicolumn{3}{|c|}{$P$-value ${ }^{2}$} \\
\hline & Mean & $\mathrm{SE}$ & $\mathrm{CON}$ & PSY & $\mathrm{SE}$ & $\mathrm{CON}$ & PSY & $\mathrm{SE}$ & $\mathrm{CON}$ & PSY & $\mathrm{SE}$ & $\mathrm{CON}$ & PSY & $\mathrm{SE}$ & $\mathrm{CON}$ & PSY & $\mathrm{SE}$ & $\mathrm{T}$ & $\mathrm{W}$ & $\mathrm{T} \times \mathrm{W}$ \\
\hline Total VFA, mmol/L & 29.6 & 4.0 & 32.9 & 52.9 & 11.4 & 73.7 & 52.0 & 11.4 & 44.4 & 61.6 & 11.4 & 56.7 & 47.3 & 9.9 & 52.0 & 53.4 & 5.5 & 0.85 & 0.41 & 0.21 \\
\hline $\begin{array}{l}\text { Acetate } \\
\mathrm{mmol} / \mathrm{L}\end{array}$ & 21.9 & 3.3 & 22.7 & 32.0 & 6.1 & 40.1 & 36.1 & 6.1 & 31.4 & 44.0 & 6.1 & 40.5 & 32.6 & 5.3 & 33.7 & 36.2 & 3.1 & 0.55 & 0.26 & 0.23 \\
\hline$\%$ & 73.3 & 3.4 & 68.9 & 61.9 & 3.6 & 58.3 & 68.7 & 3.6 & 70.6 & 71.3 & 3.6 & 71.9 & 68.1 & 3.1 & 67.4 & 67.5 & 2.1 & 0.98 & 0.09 & 0.07 \\
\hline \multicolumn{21}{|l|}{ Propionate } \\
\hline $\mathrm{mmol} / \mathrm{L}$ & 3.4 & 0.5 & 7.1 & 13.2 & 2.4 & 18.2 & 11.8 & 2.4 & 8.9 & 11.9 & 2.4 & 11.3 & 9.6 & 2.1 & 11.4 & 11.6 & 1.2 & 0.89 & 0.17 & 0.09 \\
\hline$\%$ & 15.6 & 3.3 & 22.2 & 24.8 & 2.6 & 26.7 & 24.6 & 2.6 & 20.6 & 20.0 & 2.6 & 19.5 & 21.1 & 2.4 & 22.3 & 22.6 & 2.0 & 0.80 & 0.03 & 0.62 \\
\hline \multicolumn{21}{|l|}{ Isobutyrate } \\
\hline $\mathrm{mmol} / \mathrm{L}$ & 0.45 & 0.07 & 0.5 & 1.5 & 0.4 & 1.5 & 1.0 & 0.4 & 0.8 & 1.1 & 0.4 & 1.2 & 1.0 & 0.3 & 1.0 & 1.2 & 0.2 & 0.51 & 0.91 & 0.32 \\
\hline$\%$ & 1.9 & 0.3 & 1.6 & 2.7 & 0.4 & 1.8 & 1.7 & 0.4 & 1.9 & 1.8 & 0.4 & 2.0 & 2.2 & 0.3 & 2.1 & 1.8 & 0.12 & 0.25 & 0.67 & 0.36 \\
\hline \multicolumn{21}{|l|}{ Butyrate } \\
\hline $\mathrm{mmol} / \mathrm{L}$ & 1.0 & 0.2 & 0.7 & 2.5 & 0.5 & 2.0 & 0.8 & 0.5 & 1.0 & 1.8 & 0.5 & 1.4 & 1.4 & 0.5 & 1.3 & 1.6 & 0.3 & 0.39 & 0.98 & 0.06 \\
\hline$\%$ & 3.4 & 0.5 & $2.1^{\mathrm{a}}$ & $4.6^{\mathrm{c}}$ & 0.7 & $2.6^{\mathrm{ab}}$ & $1.5^{\mathrm{a}}$ & 0.7 & $2.5^{\mathrm{ab}}$ & $3.0^{\mathrm{abc}}$ & 0.7 & $2.5^{\mathrm{ab}}$ & $3.7^{\mathrm{bc}}$ & 0.6 & 2.4 & 3.2 & 0.5 & 0.05 & 0.12 & 0.04 \\
\hline \multicolumn{21}{|l|}{ Isovalerate } \\
\hline$\%$ & 1.4 & 0.2 & 1.3 & 3.3 & 0.6 & 2.1 & 1.8 & 0.6 & 1.8 & 1.9 & 0.6 & 2.1 & 2.7 & 0.5 & 1.8 & 2.4 & 0.3 & 0.14 & 0.71 & 0.25 \\
\hline \multicolumn{21}{|l|}{ Valerate } \\
\hline $\mathrm{mmol} / \mathrm{L}$ & 1.0 & 0.2 & 1.4 & 1.6 & 2.8 & 9.9 & 1.1 & 2.8 & 1.3 & 1.4 & 2.8 & 1.2 & 1.1 & 2.4 & 3.4 & 1.3 & 1.4 & 0.27 & 0.34 & 0.30 \\
\hline$\%$ & 4.2 & 1.0 & 4.2 & 2.9 & 2.0 & 8.9 & 2.0 & 2.0 & 2.8 & 2.4 & 2.0 & 2.1 & 2.3 & 1.9 & 4.5 & 2.4 & 1.0 & 0.17 & 0.44 & 0.33 \\
\hline
\end{tabular}

${ }^{a-c}$ Means in the same row with different superscripts differ $(P<0.05)$.

${ }^{1}$ Baseline values are shown for comparison but were not included in the statistical analyses.

${ }^{2} \mathrm{~T}=$ effect of treatment, $\mathrm{W}=$ effect of week, $\mathrm{T} \times \mathrm{W}=$ treatment $\times$ week interaction. 
Table 2. Least squares means and associated standard errors for weekly concentrations (mmol/L) and molar percentages (\%) of VFA in abomasal digesta from calves fed control milk replacer (CON) or milk replacer supplemented with psyllium (PSY)

\begin{tabular}{|c|c|c|c|c|c|c|c|c|c|c|c|c|c|c|c|c|c|c|c|c|}
\hline \multirow[b]{2}{*}{ Variable } & \multicolumn{2}{|c|}{ Baseline $^{1}$} & \multicolumn{3}{|c|}{ Week 1} & \multicolumn{3}{|c|}{ Week 2} & \multicolumn{3}{|c|}{ Week 3} & \multicolumn{3}{|c|}{ Week 4} & \multicolumn{3}{|c|}{ Overall diet means } & \multicolumn{3}{|c|}{$P$-value ${ }^{2}$} \\
\hline & Mean & $\mathrm{SE}$ & $\mathrm{CON}$ & PSY & $\mathrm{SE}$ & $\mathrm{CON}$ & PSY & $\mathrm{SE}$ & $\mathrm{CON}$ & PSY & $\mathrm{SE}$ & $\mathrm{CON}$ & PSY & $\mathrm{SE}$ & $\mathrm{CON}$ & PSY & SE & $\mathrm{T}$ & W & $\mathrm{T} \times \mathrm{W}$ \\
\hline Total VFA, mmol/L & 0.7 & 0.2 & 6.8 & 12.8 & 2.9 & 12.4 & 2.9 & 2.9 & 3.5 & 3.6 & 2.9 & 4.0 & 4.8 & 2.5 & 6.7 & 6.0 & 1.4 & 0.75 & 0.14 & 0.10 \\
\hline $\begin{array}{l}\text { Acetate } \\
\text { mmol/L } \\
\%\end{array}$ & $\begin{array}{c}0.45 \\
64.1\end{array}$ & $\begin{array}{l}0.10 \\
3.6\end{array}$ & $\begin{array}{c}5.2 \\
79.4^{\text {bcd }}\end{array}$ & $\begin{array}{c}8.0 \\
67.8^{\mathrm{a}}\end{array}$ & $\begin{array}{l}1.8 \\
3.2\end{array}$ & $\begin{array}{c}8.5 \\
71.8^{\mathrm{ab}}\end{array}$ & $\begin{array}{l}2.4 \\
81.9^{\mathrm{d}}\end{array}$ & $\begin{array}{l}1.8 \\
3.2\end{array}$ & $\begin{array}{c}2.8 \\
79.6^{\mathrm{bcd}}\end{array}$ & $\begin{array}{c}2.8 \\
79.5^{\mathrm{bcd}}\end{array}$ & $\begin{array}{l}1.8 \\
3.2\end{array}$ & $\begin{array}{c}3.1 \\
80.4^{\text {cd }}\end{array}$ & $\begin{array}{c}3.6 \\
74.7^{\mathrm{abc}}\end{array}$ & $\begin{array}{l}1.5 \\
2.8\end{array}$ & $\begin{array}{r}4.9 \\
77.8\end{array}$ & $\begin{array}{r}4.2 \\
76.0\end{array}$ & $\begin{array}{l}0.9 \\
1.5\end{array}$ & $\begin{array}{l}0.58 \\
0.40\end{array}$ & $\begin{array}{l}0.14 \\
0.33\end{array}$ & $\begin{array}{l}0.11 \\
0.02\end{array}$ \\
\hline Propionate & & 0005 & 11 & 30 & 00 & 28 & 02 & 00 & 03 & 02 & 00 & 04 & 0.5 & 08 & 11 & 10 & 04 & 077 & 015 & 013 \\
\hline $\begin{array}{l}\text { mmol/L } \\
\% \\
\text { Isobutyrate }\end{array}$ & $\begin{array}{l}0.02 \\
2.7\end{array}$ & $\begin{array}{l}0.005 \\
0.6\end{array}$ & $10.8^{\mathrm{ab}}$ & $18.5^{\mathrm{bc}}$ & $\begin{array}{l}0.9 \\
3.3\end{array}$ & $\begin{array}{l}2.8^{\mathrm{c}} \\
20.4^{\mathrm{c}}\end{array}$ & $\begin{array}{l}0.2 \\
7.4^{\mathrm{a}}\end{array}$ & $\begin{array}{l}0.9 \\
3.3\end{array}$ & $\begin{array}{l}0.3 \\
7.6^{\mathrm{a}}\end{array}$ & $\begin{array}{l}0.2 \\
6.4^{\mathrm{a}}\end{array}$ & $\begin{array}{l}0.9 \\
3.3\end{array}$ & $\begin{array}{l}0.4 \\
6.5^{\mathrm{a}}\end{array}$ & $11.0^{\mathrm{ab}}$ & $\begin{array}{l}0.8 \\
2.9\end{array}$ & $\begin{array}{r}1.1 \\
11.3\end{array}$ & $\begin{array}{r}1.0 \\
10.8\end{array}$ & $\begin{array}{l}0.4 \\
1.9\end{array}$ & 0.81 & $\begin{array}{l}0.15 \\
0.05\end{array}$ & $\begin{array}{l}0.13 \\
0.01\end{array}$ \\
\hline $\mathrm{mmol} / \mathrm{L}$ & 0.01 & 0.004 & $0.1^{\mathrm{a}}$ & $0.5^{\mathrm{b}}$ & 0.1 & $0.3^{\mathrm{b}}$ & $0.1^{\mathrm{a}}$ & 0.1 & 0.1 & 0.1 & 0.1 & 0.1 & 0.2 & 0.1 & 0.1 & 0.2 & 0.05 & 0.42 & 0.09 & 0.07 \\
\hline $\begin{array}{l}\% \\
\text { Butyrate }\end{array}$ & 2.1 & 0.6 & 2.9 & 3.8 & 0.6 & 1.9 & 2.1 & 0.6 & 2.0 & 2.0 & 0.6 & 2.4 & 2.1 & 0.5 & 2.3 & 2.5 & 0.3 & 0.59 & 0.06 & 0.68 \\
\hline $\mathrm{mmol} / \mathrm{L}$ & 0.2 & 0.1 & 0.2 & 0.6 & 0.2 & 0.3 & 0.1 & 0.2 & 0.1 & 0.1 & 0.2 & 0.1 & 0.2 & 0.1 & 0.2 & 0.2 & 0.1 & 0.46 & 0.27 & 0.22 \\
\hline$\%$ & 25.4 & 4.1 & 2.4 & 4.0 & 0.7 & 2.1 & 2.1 & 0.7 & 2.1 & 2.4 & 0.7 & 2.1 & 3.9 & 0.6 & 2.2 & 3.1 & 0.3 & 0.07 & 0.27 & 0.38 \\
\hline $\begin{array}{c}\text { Isovalerate } \\
\mathrm{mmol} / \mathrm{L}\end{array}$ & 0.01 & 0.005 & 0.1 & 0.5 & 0.1 & 0.3 & 0.03 & 0.1 & 0.03 & 0.1 & 0.1 & 0.1 & 0.1 & 0.1 & 0.1 & 0.2 & 0.1 & 0.46 & 0.25 & 0.11 \\
\hline$\%$ & 1.6 & 0.8 & 1.3 & 3.5 & 0.5 & 1.8 & 1.2 & 0.5 & 1.0 & 1.9 & 0.5 & 1.0 & 1.9 & 0.5 & 1.3 & 2.1 & 0.3 & 0.03 & 0.25 & 0.11 \\
\hline $\begin{array}{l}\text { Valerate } \\
\text { mmol/L } \\
\%\end{array}$ & $\begin{array}{l}0.03 \\
4.1\end{array}$ & $\begin{array}{l}0.01 \\
0.8\end{array}$ & $\begin{array}{l}0.1 \\
3.4\end{array}$ & $\begin{array}{l}0.2 \\
2.6\end{array}$ & $\begin{array}{l}0.1 \\
1.6\end{array}$ & $\begin{array}{l}0.3 \\
2.1\end{array}$ & $\begin{array}{l}0.2 \\
5.6\end{array}$ & $\begin{array}{l}0.1 \\
1.6\end{array}$ & $\begin{array}{l}0.2 \\
7.8\end{array}$ & $\begin{array}{l}0.3 \\
8.0\end{array}$ & $\begin{array}{l}0.1 \\
1.6\end{array}$ & $\begin{array}{l}0.2 \\
7.5\end{array}$ & $\begin{array}{l}0.3 \\
7.5\end{array}$ & $\begin{array}{l}0.1 \\
1.4\end{array}$ & $\begin{array}{l}0.2 \\
5.2\end{array}$ & $\begin{array}{l}0.2 \\
5.9\end{array}$ & $\begin{array}{l}0.06 \\
1.0\end{array}$ & $\begin{array}{l}0.92 \\
0.49\end{array}$ & $\begin{array}{l}0.17 \\
0.01\end{array}$ & $\begin{array}{l}0.35 \\
0.51\end{array}$ \\
\hline
\end{tabular}

${ }^{\mathrm{a}-\mathrm{d}}$ Means in the same row with different superscripts differ $(P<0.05)$

${ }^{1}$ Baseline values are shown for comparison but were not included in the statistical analyses.

O $\quad{ }^{2} \mathrm{~T}=$ effect of treatment, $\mathrm{W}=$ effect of week, $\mathrm{T} \times \mathrm{W}=$ treatment $\times$ week interaction. 
proportion of valerate was uncharacteristically large in jejunal contents (Table 3), which may indicate that the small VFA concentrations originated at least in part from breakdown of dietary or endogenous proteins. Molar percentages of isobutyrate, butyrate, isovalerate, and valerate all exhibited a significant effect of week $(P$ $<0.01$ ), but no significant effect of treatment was observed. The small changes with age may reflect alterations in relative populations of microbial species within the small intestine but are of unknown importance.

Total VFA concentrations in digesta from the proximal colon (Table 4) and distal colon (Table 5) were the largest for any GIT segment except the reticulo-rumen. In the proximal colon, total VFA and all individual VFA except isovalerate were greater for PSY calves than for CON calves. Greater VFA concentrations for PSY calves indicate that psyllium reaching the proximal colon was fermented as in other species. A significant effect of week was also detected for individual and total VFA concentrations, whereby concentrations generally increased with greater age of the calves. Also, a significant treatment $\times$ week effect was noted for butyrate as differences between treatments were significant at wk 4 , possibly because of the increase in overall fermentation. The PSY calves had a higher percentage of propionate in digesta (Table 4), whereas CON calves had a significantly higher percentage of isovalerate. Interactions of treatment $\times$ week for percentages of acetate $(P=0.09)$ and butyrate indicate some shifting in proportions by treatment among weeks.

The concentrations and molar percentages of VFA in digesta from the distal colon (Table 5) followed the general patterns noted in the proximal colon. Concentrations of total VFA and all individual VFA except butyrate and isovalerate were greater for calves fed PSY than for those fed CON. Molar percentages of VFA were not affected by diet. The profile of VFA differed slightly from that in the proximal colon; percentages of acetate were lower (overall mean about $57.3 \%$ ), but percentages of propionate $(17.1 \%)$ and butyrate $(20.5 \%)$ were greater than comparable percentages in the proximal colon $(69.0,13.7$, and $13.5 \%$ for acetate, propionate, and butyrate, respectively).

Overall, the predominant effect of psyllium inclusion in the milk replacer on VFA concentrations was in the lower GIT as indicated by the greater total VFA concentrations in the jejunum, proximal colon, and distal colon. Greater lower gut fermentation of psyllium by intestinal bacteria corresponds to effects measured in humans (Edwards et al., 1992), rats (Edwards et al., 1992), and monkeys (Costa et al., 1989b). Psyllium resulted in only modest changes in the profile of VFA produced in the lower gut, which agrees with in vivo observations in monkeys fed psyllium (Costa et al., 1989b) or in a culture system utilizing fecal inoculum from the same monkeys (Costa et al., 1989a).

\section{Bacterial Populations in the Digestive Tract}

As a fermentable fiber, psyllium might be expected to favor colonic anaerobic bacteria with the capacity to ferment it. Although psyllium is not generally considered to be a prebiotic fiber source (Cummings and Macfarlane, 2002), its effect on establishment of desirable commensal bacteria, such as lactobacilli and bifidobacteria, in the small intestine is of interest (Yan and Polk, 2004). Increasing growth of lactobacilli and bifidobacteria in the gut may help to prevent significant proliferation of pathogenic organisms such as $E$. coli and C. perfringens (Servin, 2004). Because most of the milk replacer should have bypassed the rumen via closure of the reticular groove, effects of psyllium in milk replacer on ruminal microbial populations would be expected to be minimal.

Surprisingly, however, ruminal bifidobacteria and lactobacilli counts were greater $(P<0.05)$ for the PSY calves than for the CON calves (Table 6). Bifidobacteria counts were similar to those reported in calves by Vlková et al. (2006). The population of lactobacilli was similar to that reported for 1-wk-old calves consuming only milk (Anderson et al., 1987b). Lactobacilli counts were lowest in wk 1 and increased with age $(P<0.001)$. Differences between diets in counts of $E$. coli did not achieve statistical significance $(P=0.11)$. Likewise, no differences were detected between CON and PSY treatments for $C$. perfringens counts in the rumen. The ability of psyllium delivered in milk replacer to affect populations of bifidobacteria and lactobacilli in the undeveloped reticulo-rumen is intriguing. Whether such changes would affect development of starter intake and ruminal epithelia was not determined in this study but would be of interest to investigate. The population of lactobacilli increased by approximately 3 orders of magnitude during the first $4 \mathrm{wk}$ of life in calves offered both milk and starter (Anderson et al., 1987b). Greater rates of increase in lactobacilli populations were linked to faster rumen development (Anderson et al., 1987b).

Bacterial counts were lowest in the jejunum (Table 6) and were not affected by diet. For counts of $C$. perfringens, the diet by week interaction was significant (diet $\times$ quadratic effect of week, $P<0.05$ ) because counts were highest in wk 1 for PSY and then decreased, whereas counts were lowest at wk 1 for CON and then increased with age. Diet did not affect bacterial counts in the colon (Table 6). Bacterial counts were greatest in the colon but counts in the rumen were nearly as large. Counts generally increased with age in the colon $(P<$ 0.01) regardless of treatment. 
Table 3. Least squares means and associated standard errors for weekly concentrations (mmol/L) and molar percentages (\%) of VFA in jejunal digesta from calves fed control milk replacer $(\mathrm{CON})$ or milk replacer supplemented with psyllium (PSY)

\begin{tabular}{|c|c|c|c|c|c|c|c|c|c|c|c|c|c|c|c|c|c|c|c|c|}
\hline \multirow[b]{2}{*}{ Variable } & \multicolumn{2}{|c|}{ Baseline $^{1}$} & \multicolumn{3}{|c|}{ Week 1} & \multicolumn{3}{|c|}{ Week 2} & \multicolumn{3}{|c|}{ Week 3} & \multicolumn{3}{|c|}{ Week 4} & \multicolumn{3}{|c|}{ Overall diet means } & \multicolumn{3}{|c|}{$P$-value ${ }^{2}$} \\
\hline & Mean & $\mathrm{SE}$ & $\mathrm{CON}$ & PSY & $\mathrm{SE}$ & $\mathrm{CON}$ & PSY & $\mathrm{SE}$ & $\mathrm{CON}$ & PSY & $\mathrm{SE}$ & $\mathrm{CON}$ & PSY & $\mathrm{SE}$ & $\mathrm{CON}$ & PSY & $\mathrm{SE}$ & $\mathrm{T}$ & $\mathrm{W}$ & $\mathrm{T} \times \mathrm{W}$ \\
\hline $\begin{array}{l}\text { Total VFA, mmol/L } \\
\text { Acetate }\end{array}$ & 4.9 & 2.1 & 1.6 & 3.0 & 0.4 & 1.6 & 2.0 & 0.4 & 2.0 & 2.8 & 0.4 & 1.6 & 1.2 & 0.4 & 1.7 & 2.2 & 0.2 & 0.07 & 0.08 & 0.17 \\
\hline $\mathrm{mmol} / \mathrm{L}$ & 2.5 & 1.0 & 1.1 & 2.0 & 0.3 & 0.9 & 1.1 & 0.3 & 1.2 & 1.8 & 0.3 & 0.9 & 0.8 & 0.2 & 1.1 & 1.4 & 0.1 & 0.06 & 0.02 & 0.21 \\
\hline$\%$ & 53.8 & 1.3 & 69.0 & 65.2 & 3.5 & 61.7 & 56.5 & 3.5 & 63.2 & 65.2 & 3.5 & 59.6 & 64.1 & 3.2 & 63.4 & 62.8 & 2.2 & 0.76 & 0.10 & 0.32 \\
\hline $\begin{array}{l}\text { Propionate } \\
\mathrm{mmol} / \mathrm{L}\end{array}$ & 0.3 & 0.1 & 0.1 & 0.2 & 0.05 & 0.1 & 0.1 & 0.05 & 0.1 & 0.1 & 0.05 & 0.1 & 0.06 & 0.04 & 0.1 & 0.2 & 0.05 & 0.28 & 0.39 & 0.26 \\
\hline$\%$ & 5.6 & 0.3 & 4.7 & 6.8 & 1.3 & 6.9 & 6.4 & 1.3 & 5.4 & 5.0 & 1.3 & 5.6 & 5.5 & 1.2 & 5.6 & 5.9 & 0.8 & 0.72 & 0.60 & 0.62 \\
\hline $\begin{array}{l}\text { Isobutyrate } \\
\mathrm{mmol} / \mathrm{L}\end{array}$ & 0.09 & 0.02 & 0.04 & 0.05 & 0.03 & 0.12 & 0.11 & 0.03 & 0.10 & 0.14 & 0.03 & 0.08 & 0.05 & 0.03 & 0.08 & 0.09 & 0.02 & 0.85 & 0.04 & 0.58 \\
\hline $\begin{array}{l}\% \\
\text { Butyrate }\end{array}$ & 3.1 & 1.0 & 3.0 & 2.0 & 0.8 & 6.7 & 5.4 & 0.8 & 5.2 & 5.4 & 0.8 & 4.5 & 4.1 & 0.7 & 4.8 & 4.2 & 0.4 & 0.30 & 0.001 & 0.82 \\
\hline $\mathrm{mmol}_{\%} / \mathrm{L}$ & $\begin{array}{l}0.2 \\
4.4\end{array}$ & $\begin{array}{l}0.1 \\
0.3\end{array}$ & $\begin{array}{l}0.07 \\
4.4\end{array}$ & $\begin{array}{l}0.11 \\
3.7\end{array}$ & $\begin{array}{l}0.04 \\
1.2\end{array}$ & $\begin{array}{l}0.13 \\
6.8\end{array}$ & $\begin{array}{l}0.15 \\
6.7\end{array}$ & $\begin{array}{l}0.04 \\
1.2\end{array}$ & $\begin{array}{l}0.10 \\
5.0\end{array}$ & $\begin{array}{l}0.11 \\
4.1\end{array}$ & $\begin{array}{l}0.04 \\
1.2\end{array}$ & $\begin{array}{l}0.04 \\
2.6\end{array}$ & $\begin{array}{l}0.02 \\
1.8\end{array}$ & $\begin{array}{l}0.04 \\
1.1\end{array}$ & $\begin{array}{l}0.09 \\
4.7\end{array}$ & $\begin{array}{l}0.10 \\
4.1\end{array}$ & $\begin{array}{l}0.02 \\
0.7\end{array}$ & $\begin{array}{l}0.69 \\
0.38\end{array}$ & $\begin{array}{l}0.06 \\
0.001\end{array}$ & $\begin{array}{l}0.89 \\
0.98\end{array}$ \\
\hline $\begin{array}{l}\text { Isovalerate } \\
\text { mmol/L } \\
\%\end{array}$ & $\begin{array}{l}0.06 \\
1.3\end{array}$ & $\begin{array}{l}0.02 \\
0.5\end{array}$ & $\begin{array}{l}0.01 \\
1.3\end{array}$ & $\begin{array}{l}0.03 \\
1.0\end{array}$ & $\begin{array}{l}0.05 \\
1.0\end{array}$ & $\begin{array}{l}0.01 \\
1.1\end{array}$ & $\begin{array}{l}0.09 \\
4.2\end{array}$ & $\begin{array}{l}0.05 \\
1.0\end{array}$ & $\begin{array}{l}0.05 \\
2.6\end{array}$ & $\begin{array}{l}0.07 \\
2.6\end{array}$ & $\begin{array}{l}0.05 \\
1.0\end{array}$ & $\begin{array}{c}0.28 \\
17.1\end{array}$ & $\begin{array}{c}0.21 \\
17.1\end{array}$ & $\begin{array}{l}0.04 \\
0.8\end{array}$ & $\begin{array}{l}0.09 \\
5.5\end{array}$ & $\begin{array}{l}0.09 \\
6.2\end{array}$ & $\begin{array}{l}0.03 \\
0.6\end{array}$ & $\begin{array}{l}0.77 \\
0.23\end{array}$ & $\begin{array}{l}<0.001 \\
<0.001\end{array}$ & $\begin{array}{l}0.15 \\
0.20\end{array}$ \\
\hline $\begin{array}{l}\text { Valerate } \\
\mathrm{mmol} / \mathrm{L} \\
\%\end{array}$ & $\begin{array}{r}1.6 \\
31.8\end{array}$ & $\begin{array}{l}0.8 \\
1.8\end{array}$ & $\begin{array}{l}0.28^{\mathrm{bc}} \\
17.6\end{array}$ & $\begin{array}{l}0.61^{\mathrm{e}} \\
21.2\end{array}$ & $\begin{array}{l}0.06 \\
1.6\end{array}$ & $\begin{array}{l}0.25^{\mathrm{abc}} \\
16.8\end{array}$ & $\begin{array}{l}0.41^{\mathrm{cd}} \\
20.9\end{array}$ & $\begin{array}{l}0.06 \\
1.6\end{array}$ & $\begin{array}{l}0.36^{\mathrm{cd}} \\
18.5\end{array}$ & $\begin{array}{l}0.48^{\mathrm{de}} \\
17.6\end{array}$ & $\begin{array}{l}0.06 \\
1.6\end{array}$ & $\begin{array}{l}0.18^{\mathrm{ab}} \\
10.5\end{array}$ & $\begin{array}{l}0.09^{\mathrm{a}} \\
7.2\end{array}$ & $\begin{array}{l}0.05 \\
1.6\end{array}$ & $\begin{array}{c}0.01 \\
15.9\end{array}$ & $\begin{array}{l}0.001 \\
16.7\end{array}$ & $\begin{array}{l}0.02 \\
0.8\end{array}$ & $\begin{array}{l}0.01 \\
0.44\end{array}$ & $\begin{array}{c}0.01 \\
<0.001\end{array}$ & $\begin{array}{l}0.02 \\
0.08\end{array}$ \\
\hline
\end{tabular}

${ }^{\mathrm{a}-\mathrm{e}}$ Means in the same row with different superscripts differ $(P<0.05)$

${ }^{1}$ Baseline values are shown for comparison but were not included in the statistical analyses.

${ }^{2} \mathrm{~T}=$ effect of treatment, $\mathrm{W}=$ effect of week, $\mathrm{T} \times \mathrm{W}=$ treatment $\times$ week interaction. 
Table 4. Least squares means and associated standard errors for weekly concentrations (mmol/L) and molar percentages (\%) of VFA in the proximal colon digesta from calves fed control milk replacer (CON) or milk replacer supplemented with psyllium (PSY)

\begin{tabular}{|c|c|c|c|c|c|c|c|c|c|c|c|c|c|c|c|c|c|c|c|c|}
\hline \multirow[b]{2}{*}{ Variable } & \multicolumn{2}{|c|}{ Baseline $^{1}$} & \multicolumn{3}{|c|}{ Week 1} & \multicolumn{3}{|c|}{ Week 2} & \multicolumn{3}{|c|}{ Week 3} & \multicolumn{3}{|c|}{ Week 4} & \multicolumn{3}{|c|}{ Overall diet means } & \multicolumn{3}{|c|}{$P$-value ${ }^{2}$} \\
\hline & Mean & $\mathrm{SE}$ & $\mathrm{CON}$ & PSY & $\mathrm{SE}$ & $\mathrm{CON}$ & PSY & $\mathrm{SE}$ & $\mathrm{CON}$ & PSY & $\mathrm{SE}$ & $\mathrm{CON}$ & PSY & $\mathrm{SE}$ & $\mathrm{CON}$ & PSY & $\mathrm{SE}$ & $\mathrm{T}$ & W & $\mathrm{T} \times \mathrm{W}$ \\
\hline $\begin{array}{l}\text { Total VFA, mmol/L } \\
\text { Acetate }\end{array}$ & 7.5 & 1.1 & 11.6 & 20.4 & 6.4 & 18.6 & 34.9 & 6.4 & 20.4 & 37.3 & 6.4 & 21.7 & 55.3 & 5.6 & 18.1 & 37.0 & 3.1 & $<0.001$ & 0.01 & 0.20 \\
\hline$\underset{\%}{\mathrm{mmol} / \mathrm{L}}$ & $\begin{array}{r}6.0 \\
79.1\end{array}$ & $\begin{array}{l}0.9 \\
3.2\end{array}$ & $\begin{array}{c}9.0 \\
78.2^{\mathrm{b}}\end{array}$ & $\begin{array}{l}13.9 \\
68.4^{\mathrm{a}}\end{array}$ & $\begin{array}{l}4.4 \\
3.3\end{array}$ & $\begin{array}{l}11.8 \\
62.8^{\mathrm{a}}\end{array}$ & $\begin{array}{l}24.4 \\
69.6^{\mathrm{ab}}\end{array}$ & $\begin{array}{l}4.4 \\
3.3\end{array}$ & $\begin{array}{l}12.8 \\
61.8^{\mathrm{a}}\end{array}$ & $\begin{array}{l}27.6 \\
74.4^{\mathrm{b}}\end{array}$ & $\begin{array}{l}4.4 \\
3.3\end{array}$ & $\begin{array}{l}15.4 \\
70.3^{\mathrm{ab}}\end{array}$ & $\begin{array}{l}36.6 \\
66.3^{\mathrm{a}}\end{array}$ & $\begin{array}{l}3.8 \\
2.9\end{array}$ & $\begin{array}{l}12.2 \\
68.2\end{array}$ & $\begin{array}{l}25.6 \\
69.7\end{array}$ & $\begin{array}{l}2.1 \\
1.6\end{array}$ & $\begin{array}{c}<0.001 \\
0.54\end{array}$ & $\begin{array}{l}0.02 \\
0.21\end{array}$ & $\begin{array}{l}0.29 \\
0.01\end{array}$ \\
\hline Propionate & & & & & & & & & & & & & & & & & & & & \\
\hline $\begin{array}{l}\mathrm{mmol} / \mathrm{L} \\
\% \\
\text { Isobutyrate }\end{array}$ & $\begin{array}{l}0.4 \\
3.0\end{array}$ & $\begin{array}{l}0.1 \\
1.1\end{array}$ & $\begin{array}{l}1.0 \\
7.0\end{array}$ & $\begin{array}{r}2.6 \\
12.7\end{array}$ & $\begin{array}{l}1.4 \\
2.5\end{array}$ & $\begin{array}{r}2.9 \\
15.4\end{array}$ & $\begin{array}{r}6.3 \\
18.8\end{array}$ & $\begin{array}{l}1.4 \\
2.5\end{array}$ & $\begin{array}{r}3.3 \\
16.1\end{array}$ & $\begin{array}{r}6.2 \\
16.0\end{array}$ & $\begin{array}{l}1.4 \\
2.5\end{array}$ & $\begin{array}{r}2.3 \\
10.9\end{array}$ & $\begin{array}{r}7.3 \\
12.8\end{array}$ & $\begin{array}{l}1.2 \\
2.3\end{array}$ & $\begin{array}{r}2.4 \\
12.4\end{array}$ & $\begin{array}{r}5.6 \\
15.1\end{array}$ & $\begin{array}{l}0.8 \\
1.9\end{array}$ & $\begin{array}{l}0.001 \\
0.04\end{array}$ & $\begin{array}{l}0.07 \\
0.003\end{array}$ & $\begin{array}{l}0.55 \\
0.47\end{array}$ \\
\hline $\mathrm{m}_{\%}$ & $\begin{array}{l}0.1 \\
5.5\end{array}$ & $\begin{array}{l}0.06 \\
3.3\end{array}$ & $\begin{array}{l}0.04^{\mathrm{a}} \\
0.35^{\mathrm{ab}}\end{array}$ & $\begin{array}{l}0.19^{\mathrm{b}} \\
0.92^{\mathrm{bc}}\end{array}$ & $\begin{array}{l}0.05 \\
0.22\end{array}$ & $\begin{array}{l}0.10^{\mathrm{ab}} \\
0.57^{\mathrm{abc}}\end{array}$ & $\begin{array}{l}0.17^{\mathrm{ab}} \\
0.53^{\mathrm{abc}}\end{array}$ & $\begin{array}{l}0.05 \\
0.22\end{array}$ & $\begin{array}{l}0.18^{\mathrm{ab}} \\
0.84^{\mathrm{bc}}\end{array}$ & $\begin{array}{l}0.03^{\mathrm{a}} \\
0.11^{\mathrm{a}}\end{array}$ & $\begin{array}{l}0.05 \\
0.22\end{array}$ & $\begin{array}{l}0.14^{\mathrm{ab}} \\
0.64^{\mathrm{abc}}\end{array}$ & $\begin{array}{l}0.37^{\mathrm{c}} \\
0.94^{\mathrm{c}}\end{array}$ & $\begin{array}{l}0.04 \\
0.19\end{array}$ & $\begin{array}{l}0.12 \\
0.60\end{array}$ & $\begin{array}{l}0.19 \\
0.62\end{array}$ & $\begin{array}{l}0.025 \\
0.11\end{array}$ & $\begin{array}{l}0.05 \\
0.88\end{array}$ & $\begin{array}{l}0.02 \\
0.46\end{array}$ & $\begin{array}{l}0.01 \\
0.05\end{array}$ \\
\hline $\begin{array}{l}\text { Butyrate } \\
\text { mmol/L } \\
\%\end{array}$ & $\begin{array}{l}0.4 \\
5.5\end{array}$ & $\begin{array}{l}0.15 \\
1.5\end{array}$ & $\begin{array}{l}1.2^{\mathrm{a}} \\
9.3^{\mathrm{ab}}\end{array}$ & $\begin{array}{c}3.2^{\mathrm{a}} \\
15.1^{\mathrm{ab}}\end{array}$ & $\begin{array}{l}1.2 \\
3.5\end{array}$ & $\begin{array}{r}3.1^{\mathrm{a}} \\
17.0^{\mathrm{b}}\end{array}$ & $\begin{array}{l}3.3^{\mathrm{a}} \\
8.7^{\mathrm{a}}\end{array}$ & $\begin{array}{l}1.2 \\
3.5\end{array}$ & $\begin{array}{r}3.4^{\mathrm{a}} \\
17.7^{\mathrm{b}}\end{array}$ & $\begin{array}{l}3.3^{\mathrm{a}} \\
8.7^{\mathrm{a}}\end{array}$ & $\begin{array}{l}1.2 \\
3.5\end{array}$ & $\begin{array}{c}3.1^{\mathrm{a}} \\
14.4^{\mathrm{ab}}\end{array}$ & $\begin{array}{r}9.2^{\mathrm{b}} \\
16.8^{\mathrm{b}}\end{array}$ & $\begin{array}{l}1.1 \\
3.1\end{array}$ & $\begin{array}{r}2.7 \\
14.6\end{array}$ & $\begin{array}{r}4.8 \\
12.3\end{array}$ & $\begin{array}{l}0.7 \\
2.3\end{array}$ & $\begin{array}{l}0.02 \\
0.28\end{array}$ & $\begin{array}{l}0.01 \\
0.62\end{array}$ & $\begin{array}{l}0.03 \\
0.05\end{array}$ \\
\hline $\begin{array}{l}\text { Isovalerate } \\
\mathrm{mmol} / \mathrm{L} \\
\%\end{array}$ & $\begin{array}{l}0.3 \\
4.5\end{array}$ & $\begin{array}{l}0.08 \\
0.8\end{array}$ & $\begin{array}{l}0.20^{\mathrm{a}} \\
2.0\end{array}$ & $\begin{array}{l}0.13^{\mathrm{a}} \\
0.6\end{array}$ & $\begin{array}{l}0.13 \\
0.7\end{array}$ & $\begin{array}{l}0.27^{\mathrm{a}} \\
1.5\end{array}$ & $\begin{array}{l}0.22^{\mathrm{a}} \\
0.6\end{array}$ & $\begin{array}{l}0.13 \\
0.7\end{array}$ & $\begin{array}{l}0.37^{\mathrm{ab}} \\
1.8\end{array}$ & $\begin{array}{l}0.06^{\mathrm{a}} \\
0.2\end{array}$ & $\begin{array}{l}0.13 \\
0.7\end{array}$ & $\begin{array}{l}0.20^{\mathrm{a}} \\
1.0\end{array}$ & $\begin{array}{l}0.61^{\mathrm{b}} \\
1.1\end{array}$ & $\begin{array}{l}0.11 \\
0.6\end{array}$ & $\begin{array}{l}0.26 \\
1.6\end{array}$ & $\begin{array}{l}0.25 \\
0.6\end{array}$ & $\begin{array}{l}0.07 \\
0.3\end{array}$ & $\begin{array}{l}0.92 \\
0.06\end{array}$ & $\begin{array}{l}0.18 \\
0.97\end{array}$ & $\begin{array}{l}0.03 \\
0.44\end{array}$ \\
\hline $\begin{array}{l}\text { Valerate } \\
\mathrm{mmol} / \mathrm{L} \\
\%\end{array}$ & $\begin{array}{l}0.2 \\
2.3\end{array}$ & $\begin{array}{l}0.05 \\
0.4\end{array}$ & $\begin{array}{l}0.34 \\
3.2\end{array}$ & $\begin{array}{l}0.42 \\
2.2\end{array}$ & $\begin{array}{l}0.30 \\
1.0\end{array}$ & $\begin{array}{l}0.50 \\
2.7\end{array}$ & $\begin{array}{l}0.55 \\
1.6\end{array}$ & $\begin{array}{l}0.30 \\
1.0\end{array}$ & $\begin{array}{l}0.41 \\
1.7\end{array}$ & $\begin{array}{l}0.24 \\
0.7\end{array}$ & $\begin{array}{l}0.30 \\
1.0\end{array}$ & $\begin{array}{l}0.57 \\
2.7\end{array}$ & $\begin{array}{l}1.16 \\
2.0\end{array}$ & $\begin{array}{l}0.26 \\
0.9\end{array}$ & $\begin{array}{l}0.45 \\
2.6\end{array}$ & $\begin{array}{l}0.59 \\
1.6\end{array}$ & $\begin{array}{l}0.14 \\
0.5\end{array}$ & $\begin{array}{l}0.50 \\
0.19\end{array}$ & $\begin{array}{l}0.20 \\
0.53\end{array}$ & $\begin{array}{l}0.54 \\
0.99\end{array}$ \\
\hline
\end{tabular}

${ }^{\mathrm{a}-\mathrm{c}}$ Means in the same row with different superscripts differ $(P<0.05)$.

${ }^{1}$ Baseline values are shown for comparison but were not included in the statistical analyses.

${ }^{2} \mathrm{~T}=$ effect of treatment, $\mathrm{W}=$ effect of week, $\mathrm{T} \times \mathrm{W}=$ treatment $\times$ week interaction. 
Table 5. Least squares means and associated standard errors for weekly concentrations (mmol/L) and molar percentages (\%) of VFA in distal colon digesta from calves fed control milk replacer (CON) or milk replacer supplemented with psyllium (PSY)

\begin{tabular}{|c|c|c|c|c|c|c|c|c|c|c|c|c|c|c|c|c|c|c|c|c|}
\hline \multirow[b]{2}{*}{ Variable } & \multicolumn{2}{|c|}{ Baseline $^{1}$} & \multicolumn{3}{|c|}{ Week 1} & \multicolumn{3}{|c|}{ Week 2} & \multicolumn{3}{|c|}{ Week 3} & \multicolumn{3}{|c|}{ Week 4} & \multicolumn{3}{|c|}{ Overall diet means } & \multicolumn{3}{|c|}{$P$-value ${ }^{2}$} \\
\hline & Mean & $\mathrm{SE}$ & $\mathrm{CON}$ & PSY & $\mathrm{SE}$ & $\mathrm{CON}$ & PSY & $\mathrm{SE}$ & $\mathrm{CON}$ & PSY & $\mathrm{SE}$ & $\mathrm{CON}$ & PSY & $\mathrm{SE}$ & $\mathrm{CON}$ & PSY & $\mathrm{SE}$ & $\mathrm{T}$ & $\mathrm{W}$ & $\mathrm{T} \times \mathrm{W}$ \\
\hline $\begin{array}{l}\text { Total VFA, mmol/L } \\
\text { Acetate }\end{array}$ & 12.3 & 1.9 & 22.6 & 23.6 & 4.5 & 25.7 & 44.8 & 4.5 & 19.4 & 31.8 & 5.1 & 24.1 & 33.6 & 4.2 & 23.0 & 33.5 & 3.4 & $<0.001$ & 0.02 & 0.11 \\
\hline $\operatorname{mmol}_{\%} / \mathrm{L}$ & $\begin{array}{r}8.8 \\
69.0\end{array}$ & $\begin{array}{l}2.1 \\
6.7\end{array}$ & $\begin{array}{l}15.7 \\
67.7\end{array}$ & $\begin{array}{l}14.4 \\
61.7\end{array}$ & $\begin{array}{l}3.1 \\
5.0\end{array}$ & $\begin{array}{l}13.0 \\
52.1\end{array}$ & $\begin{array}{l}27.2 \\
59.9\end{array}$ & $\begin{array}{l}3.1 \\
5.0\end{array}$ & $\begin{array}{r}9.2 \\
47.2\end{array}$ & $\begin{array}{l}17.6 \\
54.0\end{array}$ & $\begin{array}{l}3.1 \\
5.9\end{array}$ & $\begin{array}{l}14.5 \\
59.8\end{array}$ & $\begin{array}{l}21.2 \\
56.3\end{array}$ & $\begin{array}{l}2.7 \\
4.6\end{array}$ & $\begin{array}{l}13.1 \\
56.7\end{array}$ & $\begin{array}{l}20.1 \\
58.0\end{array}$ & $\begin{array}{l}1.6 \\
3.3\end{array}$ & $\begin{array}{l}0.004 \\
0.69\end{array}$ & $\begin{array}{l}0.18 \\
0.06\end{array}$ & $\begin{array}{l}0.12 \\
0.33\end{array}$ \\
\hline $\begin{array}{l}\text { Propionate } \\
\mathrm{mmol} / \mathrm{L}\end{array}$ & 0.6 & 0.2 & 3.1 & 3.8 & 1.1 & 4.6 & 10.0 & 1.1 & 3.7 & 6.1 & 1.1 & 4.0 & 5.9 & 1.0 & 3.8 & 6.4 & 0.6 & 0.004 & 0.02 & 0.22 \\
\hline $\begin{array}{l}\% \\
\text { Isobutyrate }\end{array}$ & 6.4 & 2.2 & 12.6 & 14.8 & 3.1 & 17.1 & 22.0 & 3.1 & 20.2 & 20.0 & 3.8 & 16.3 & 13.4 & 2.7 & 16.6 & 17.6 & 1.6 & 0.66 & 0.014 & 0.60 \\
\hline $\mathrm{mmol}_{\%} \mathrm{~L}$ & $\begin{array}{l}0.1 \\
0.6\end{array}$ & $\begin{array}{l}0.03 \\
0.2\end{array}$ & $\begin{array}{l}0.16 \\
0.6\end{array}$ & $\begin{array}{l}0.23 \\
0.9\end{array}$ & $\begin{array}{l}0.09 \\
0.4\end{array}$ & $\begin{array}{l}0.24 \\
0.8\end{array}$ & $\begin{array}{l}0.38 \\
0.8\end{array}$ & $\begin{array}{l}0.09 \\
0.4\end{array}$ & $\begin{array}{l}0.24 \\
1.3\end{array}$ & $\begin{array}{l}0.33 \\
1.2\end{array}$ & $\begin{array}{l}0.09 \\
0.4\end{array}$ & $\begin{array}{l}0.35 \\
1.6\end{array}$ & $\begin{array}{l}0.58 \\
2.0\end{array}$ & $\begin{array}{l}0.07 \\
0.3\end{array}$ & $\begin{array}{l}0.25 \\
1.1\end{array}$ & $\begin{array}{l}0.38 \\
1.2\end{array}$ & $\begin{array}{l}0.04 \\
0.2\end{array}$ & $\begin{array}{l}0.05 \\
0.70\end{array}$ & $\begin{array}{l}0.03 \\
0.03\end{array}$ & $\begin{array}{l}0.75 \\
0.88\end{array}$ \\
\hline $\begin{array}{l}\text { Butyrate } \\
\mathrm{mmol} / \mathrm{L} \\
\%\end{array}$ & $\begin{array}{r}2.5 \\
21.9\end{array}$ & $\begin{array}{l}0.9 \\
5.9\end{array}$ & $\begin{array}{r}3.4 \\
17.2\end{array}$ & $\begin{array}{r}4.2 \\
18.7\end{array}$ & $\begin{array}{l}2.5 \\
4.5\end{array}$ & $\begin{array}{r}7.2 \\
27.3\end{array}$ & $\begin{array}{r}6.2 \\
14.4\end{array}$ & $\begin{array}{l}2.5 \\
4.5\end{array}$ & $\begin{array}{r}5.2 \\
25.9\end{array}$ & $\begin{array}{r}7.2 \\
22.5\end{array}$ & $\begin{array}{l}2.5 \\
5.0\end{array}$ & $\begin{array}{r}4.2 \\
17.6\end{array}$ & $\begin{array}{r}8.4 \\
20.7\end{array}$ & $\begin{array}{l}2.4 \\
4.2\end{array}$ & $\begin{array}{r}5.0 \\
22.0\end{array}$ & $\begin{array}{r}6.5 \\
19.1\end{array}$ & $\begin{array}{l}2.1 \\
3.6\end{array}$ & $\begin{array}{l}0.18 \\
0.21\end{array}$ & $\begin{array}{l}0.25 \\
0.30\end{array}$ & $\begin{array}{l}0.33 \\
0.07\end{array}$ \\
\hline $\begin{array}{l}\text { Isovalerate } \\
\mathrm{mmol} / \mathrm{L}\end{array}$ & 0.1 & 0.04 & 0.30 & 0.45 & 0.24 & 0.47 & 0.34 & 0.24 & 0.69 & 0.30 & 0.24 & 0.50 & 1.05 & 0.21 & 0.49 & 0.53 & 0.12 & 0.80 & 0.25 & 0.22 \\
\hline
\end{tabular}

疍 ${ }^{1}$ Baseline values are shown for comparison but were not included in the statistical analyses.

$\stackrel{0}{0} \quad{ }^{2} \mathrm{~T}=$ effect of treatment, $\mathrm{W}=$ effect of week, $\mathrm{T} \times \mathrm{W}=$ treatment $\times$ week interaction. 
Overall, effects of psyllium inclusion on bacterial counts were minimal except in the reticulo-rumen. Increased rumen bifidobacteria and lactobacilli populations indicate a potential effect of psyllium inclusion as a prebiotic due to small amounts of milk replacer entering the rumen through incomplete closure of the reticular groove. No significant differences in bifidobacteria and lactobacilli populations were observed in the jejunum or colon. The lack of differences may indicate that the existing populations had the capacity to metabolize the added psyllium without affecting the balance of bacterial genera (Swanson et al., 2002).

\section{Weight, Length, and Density of Gastrointestinal Tract}

Luminal VFA from lower gut fermentation can increase mass and tissue thickness not only in the compartment in which they are produced but also in other segments of the GIT (Tappenden et al., 2003). A tendency was noted $(P<0.09)$ for the PSY calves to have heavier reticulo-rumens (Table 7 ). The effect of week was significant for reticulo-rumen weight, and tendencies for an effect of week were noted for reticulorumen length and density of reticulo-rumen tissue. No significant differences were noted between PSY and CON treatments for omasal or abomasal measurements (Table 7). Effects of week were significant for omasal mass-specific length $(\mathrm{cm} / \mathrm{kg}$ of $\mathrm{BW})$ and abomasal length and mass-specific length (Table 7). There was a tendency for an effect of week $(P<0.09)$ on abomasal mass-specific weight $(\mathrm{g} / \mathrm{kg}$ of $\mathrm{BW})$, which indicated that the abomasum tended to decrease in size relative to the rest of the body as calves grew.

Effects of diet were more pronounced in the jejunum (Table 8$)$. The CON calves tended $(P<0.09)$ to have longer jejunums and exhibited greater $(P<0.01)$ length of jejunal tissue per kilogram of calf BW than did the PSY calves from wk 2 to 4 (treatment $\times$ week interaction, $P=0.03)$. The PSY calves had larger mean jejunal weight and tended $(P=0.056)$ to have a larger mass of jejunum per kilogram of BW. Furthermore, the PSY calves exhibited significantly denser jejunal tissue than CON calves, although the significant treatment $\times$ week interaction indicated that this occurred only after wk 1.

Calves fed PSY had greater $(P<0.01)$ duodenal weights (Table 9) and more duodenal tissue per kilogram of BW $(P<0.02)$ than calves fed CON. The PSY calves also tended $(P<0.06)$ to have more dense duodenal tissues. Ileal length and mass were not affected by diet, but ileal tissue had greater density in PSY calves than in CON calves (Table 9). The effect of treatment was significant for colon weight, with the

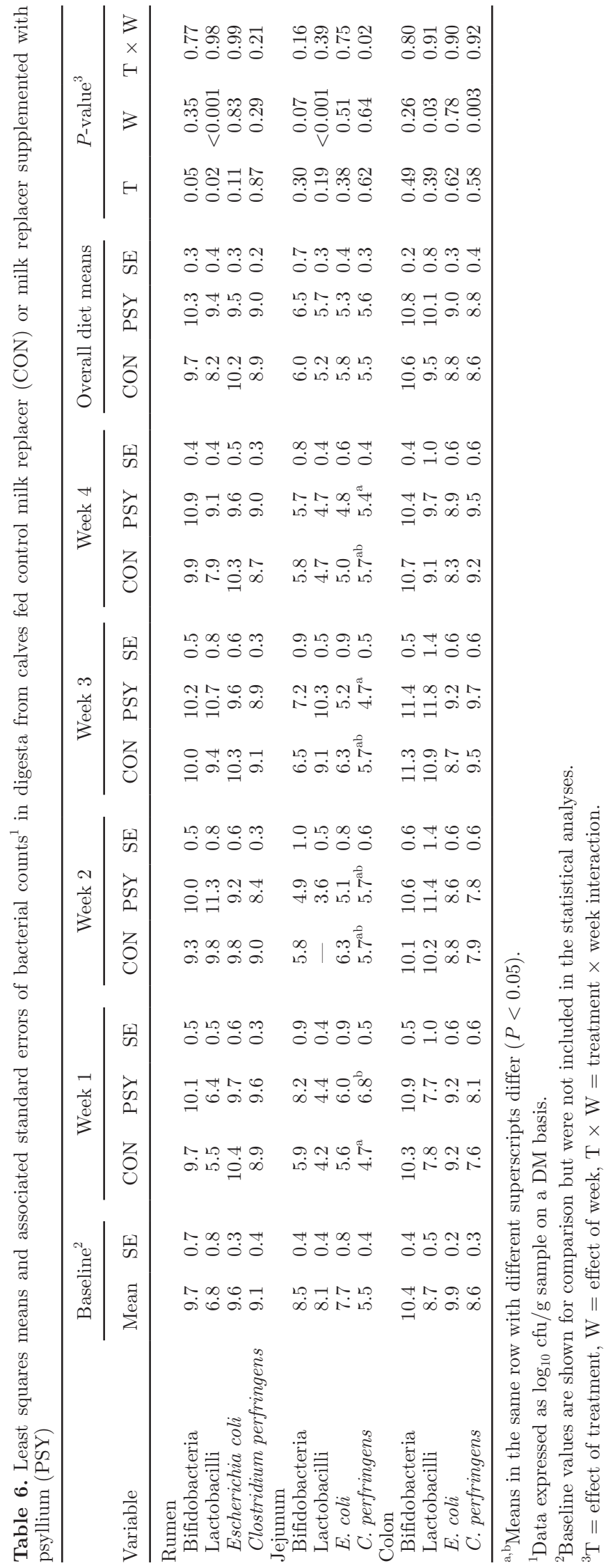


Table 7. Least squares means and associated standard errors for weekly measurements of stomach compartments from calves fed control milk replacer (CON) or milk replacer supplemented with psyllium (PSY)

\begin{tabular}{|c|c|c|c|c|c|c|c|c|c|c|c|c|c|c|c|c|c|c|c|c|}
\hline \multirow[b]{2}{*}{ Variable } & \multicolumn{2}{|c|}{ Baseline $^{1}$} & \multicolumn{3}{|c|}{ Week 1} & \multicolumn{3}{|c|}{ Week 2} & \multicolumn{3}{|c|}{ Week 3} & \multicolumn{3}{|c|}{ Week 4} & \multicolumn{3}{|c|}{ Overall diet means } & \multicolumn{3}{|c|}{$P$-value ${ }^{2}$} \\
\hline & Mean & $\mathrm{SE}$ & $\mathrm{CON}$ & PSY & $\mathrm{SE}$ & $\mathrm{CON}$ & PSY & $\mathrm{SE}$ & $\mathrm{CON}$ & PSY & $\mathrm{SE}$ & $\mathrm{CON}$ & PSY & $\mathrm{SE}$ & $\mathrm{CON}$ & PSY & $\mathrm{SE}$ & $\mathrm{T}$ & $\mathrm{W}$ & $\mathrm{T} \times \mathrm{W}$ \\
\hline \multicolumn{21}{|l|}{ Reticulo-rumen } \\
\hline \multicolumn{21}{|l|}{ Length } \\
\hline $\mathrm{cm}$ & 24.7 & 1.2 & 26.5 & 31.8 & 2.2 & 29.8 & 30.8 & 2.2 & 32.0 & 33.8 & 2.2 & 33.8 & 33.1 & 2.0 & 30.5 & 32.4 & 1.5 & 0.15 & 0.07 & 0.39 \\
\hline $\begin{array}{l}\mathrm{cm} / \mathrm{kg} \text { of } \mathrm{BW} \\
\text { Weight }\end{array}$ & 0.49 & 0.04 & 0.60 & 0.69 & 0.04 & 0.65 & 0.70 & 0.04 & 0.64 & 0.63 & 0.04 & 0.63 & 0.61 & 0.04 & 0.63 & 0.66 & 0.02 & 0.31 & 0.49 & 0.50 \\
\hline $\mathrm{g}$ & 182 & 6.4 & 184 & 238 & 25 & 249 & 211 & 25 & 243 & 313 & 25 & 255 & 280 & 22 & 233 & 261 & 15 & 0.09 & 0.03 & 0.13 \\
\hline $\mathrm{g} / \mathrm{kg}$ of $\mathrm{BW}$ & 3.73 & 0.10 & 4.14 & 5.17 & 0.40 & 5.39 & 4.82 & 0.40 & 4.87 & 5.80 & 0.40 & 4.74 & 5.12 & 0.35 & 4.79 & 5.23 & 0.20 & 0.12 & 0.39 & 0.20 \\
\hline Density, $\mathrm{g} / \mathrm{cm}$ & 7.5 & 0.3 & $6.9^{\mathrm{a}}$ & $7.5^{\mathrm{ab}}$ & 0.5 & $8.3^{\text {bcd }}$ & $6.8^{\mathrm{a}}$ & 0.5 & $7.6^{\mathrm{abc}}$ & $9.2^{\mathrm{d}}$ & 0.5 & $7.6^{\mathrm{abc}}$ & $8.5^{\mathrm{cd}}$ & 0.4 & 7.6 & 8.0 & 0.2 & 0.25 & 0.09 & 0.03 \\
\hline \multicolumn{21}{|l|}{ Omasum } \\
\hline \multicolumn{21}{|l|}{ Length } \\
\hline & 6.8 & 0.2 & 6.6 & 6.7 & 0.6 & 9.2 & 6.8 & 0.6 & 7.3 & 7.3 & 0.6 & 7.1 & 7.2 & 0.5 & 7.6 & 7.0 & 0.3 & 0.18 & 0.16 & 0.13 \\
\hline $\mathrm{cm} / \mathrm{kg}$ of $\mathrm{BW}$ & 0.14 & 0.01 & 0.15 & 0.15 & 0.01 & 0.20 & 0.16 & 0.01 & 0.15 & 0.14 & 0.01 & 0.13 & 0.13 & 0.01 & 0.16 & 0.14 & 0.01 & 0.11 & 0.01 & 0.28 \\
\hline $\begin{array}{l}\text { Welght } \\
\mathrm{g}\end{array}$ & 68.5 & 3.8 & 59.5 & 63.6 & 8.6 & 83.3 & 66.9 & 8.6 & 80.8 & 71.1 & 8.6 & 78.5 & 75.5 & 7.5 & 75.5 & 69.3 & 4.2 & 0.30 & 0.25 & 0.67 \\
\hline $\mathrm{g} / \mathrm{kg}$ of $\mathrm{BW}$ & 1.40 & 0.07 & 1.37 & 1.38 & 0.14 & 1.81 & 1.53 & 0.14 & 1.64 & 1.35 & 0.14 & 1.44 & 1.37 & 0.12 & 1.57 & 1.41 & 0.07 & 0.11 & 0.16 & 0.61 \\
\hline Density, $\mathrm{g} / \mathrm{cm}$ & 10.0 & 0.5 & 9.0 & 9.4 & 1.1 & 9.5 & 9.7 & 1.1 & 11.1 & 9.7 & 1.1 & 11.0 & 10.6 & 1.0 & 10.1 & 9.9 & 0.5 & 0.74 & 0.43 & 0.86 \\
\hline \multicolumn{21}{|l|}{ Abomasum } \\
\hline \multicolumn{21}{|l|}{ Length } \\
\hline & 35.3 & 4.2 & 31.2 & 36.7 & 1.7 & 28.8 & 29.7 & 1.7 & 35.7 & 33.2 & 1.7 & 32.9 & 34.6 & 1.4 & 32.1 & 33.5 & 0.8 & 0.23 & 0.02 & 0.15 \\
\hline \multicolumn{21}{|l|}{ Weight } \\
\hline & 278 & 11.6 & & 257 & 21 & 255 & 231 & 21 & 240 & 255 & 21 & 240 & 264 & 19 & 240 & 252 & 12.5 & 0.39 & 0.92 & 0.50 \\
\hline $\mathrm{g} / \mathrm{kg}$ of $\mathrm{BW}$ & 5.58 & 0.25 & 5.07 & 5.55 & 0.36 & 5.53 & 5.26 & 0.36 & 4.81 & 4.74 & 0.36 & 4.46 & 4.86 & 0.31 & 4.97 & 5.10 & 0.17 & 0.59 & 0.09 & 0.65 \\
\hline Density, $\mathrm{g} / \mathrm{cm}$ & 7.3 & 0.4 & 7.2 & 7.0 & 0.7 & 8.8 & 7.9 & 0.7 & 7.6 & 6.8 & 0.7 & 7.4 & 7.8 & 0.6 & 7.5 & 7.6 & 0.4 & 0.89 & 0.23 & 0.54 \\
\hline \multicolumn{21}{|c|}{${ }^{\mathrm{a}-\mathrm{d}}$ Means in the same row with different superscripts differ $(P<0.05)$. } \\
\hline \multirow{2}{*}{\multicolumn{21}{|c|}{$\begin{array}{l}{ }^{1} \text { Baseline values are shown for comparison but were not included in the statistical analyses. } \\
{ }^{2} \mathrm{~T}=\text { effect of treatment, } \mathrm{W}=\text { effect of week, } \mathrm{T} \times \mathrm{W}=\text { treatment } \times \text { week interaction. }\end{array}$}} \\
\hline & & & & & & & & & & & & & & & & & & & & \\
\hline & & & & & & & & & & & & & & & & & & & & \\
\hline & & & & & & & & & & & & & & & & & & & & \\
\hline & & & & & & & & & & & & & & & & & & & & \\
\hline & & & & & & & & & & & & & & & & & & & & \\
\hline & & & & & & & & & & & & & & & & & & & & \\
\hline & & & & & & & & & & & & & & & & & & & & \\
\hline
\end{tabular}




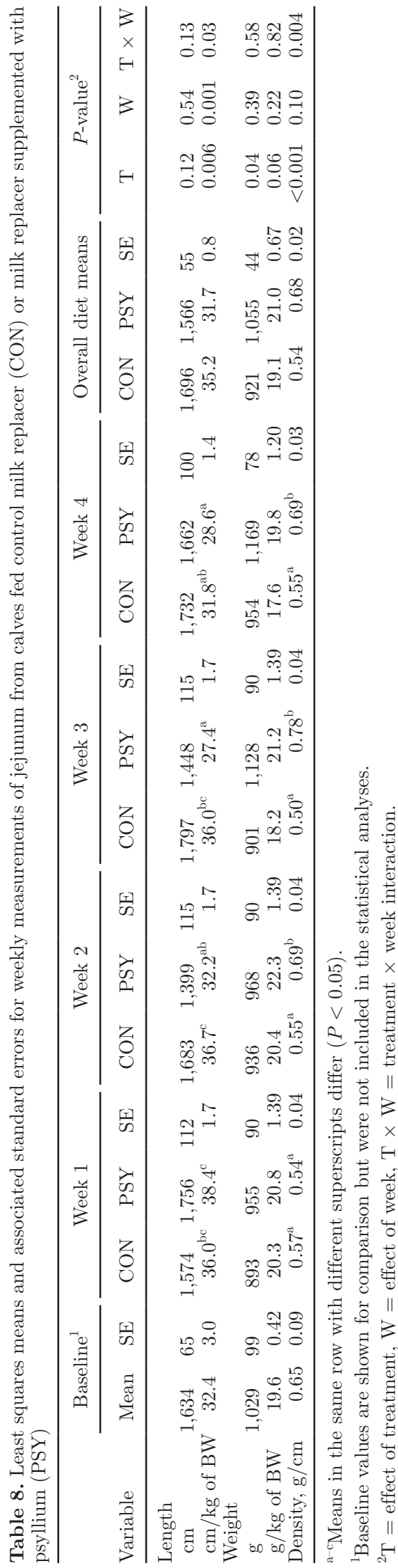

PSY calves having heavier colons (both in grams and relative to calf $\mathrm{BW}$ ) than $\mathrm{CON}$ calves (Table 9). The PSY calves also tended $(P<0.06)$ to have greater density of colonic tissue than the CON calves. The total GIT weight was $12 \%$ greater $(P<0.05)$ for PSY calves (Table 9); expressed as a percentage of BW, the total GIT was $9.5 \%$ greater for PSY calves $(P<0.01$; Table 9).

Inclusion of psyllium in milk replacer did not increase length of the duodenum $(P=0.89)$, jejunum $(P=$ $0.12)$, ileum $(P=0.51)$, or colon $(P=0.51)$. These data contrast with the effects observed in rats, where lengths of the small intestine (Leng-Peschlow, 1991) and large intestine (Leng-Peschlow, 1991; Edwards et al., 1992) were increased when psyllium was included in the diet. However, the greater wet weights of duodenum, jejunum, and colon for the PSY calves agree with data from rats fed psyllium, which had greater weights of small intestine (Schneeman and Richter, 1993) and colon (Edwards et al., 1992). The increased tissue density of duodenum, jejunum, ileum, and colon for calves consuming psyllium was similar to the increased density of small intestine and colon observed in rats (Leng-Peschlow, 1991).

The increase in mass and density of the GIT for calves consuming psyllium could be of benefit to the neonatal dairy calf from a standpoint of potentially greater absorptive capacities of the tissue plus greater tissue resistance to pathogen intrusion into the body. On the other hand, a greater mass of GIT would increase maintenance requirements for nutrients and energy, although there were no differences in ADG of calves in this experiment (Cannon et al., 2010). Fecal scores and respiratory scores were also not different between treatments (Cannon et al., 2010), but the numbers of calves in this experiment were insufficient to make conclusions about effects on health under field conditions.

\section{CONCLUSIONS}

Addition of psyllium to milk replacer increased VFA concentrations in the hindgut of neonatal calves fed only milk replacer. In turn, the greater VFA production resulted in increased mass of total GIT as well as several of the individual GIT components. A greater mass and density of GIT, particularly in the small intestine, could be of benefit to milk-fed calves through greater digestive capacity and increased resistance to pathogen entry. The significant increase in populations of bifidobacteria and lactobacilli in the reticulo-rumen was unexpected and intriguing; the potential implications on intake and rumen epithelial development in calves also offered starter should be investigated. The lack of significant changes in populations of bifidobacteria 
Table 9. Least squares means and associated standard errors for measurements of duodenum, ileum, colon, and total gastrointestinal tract (GIT) from calves fed control milk replacer (CON) or milk replacer supplemented with psyllium (PSY)

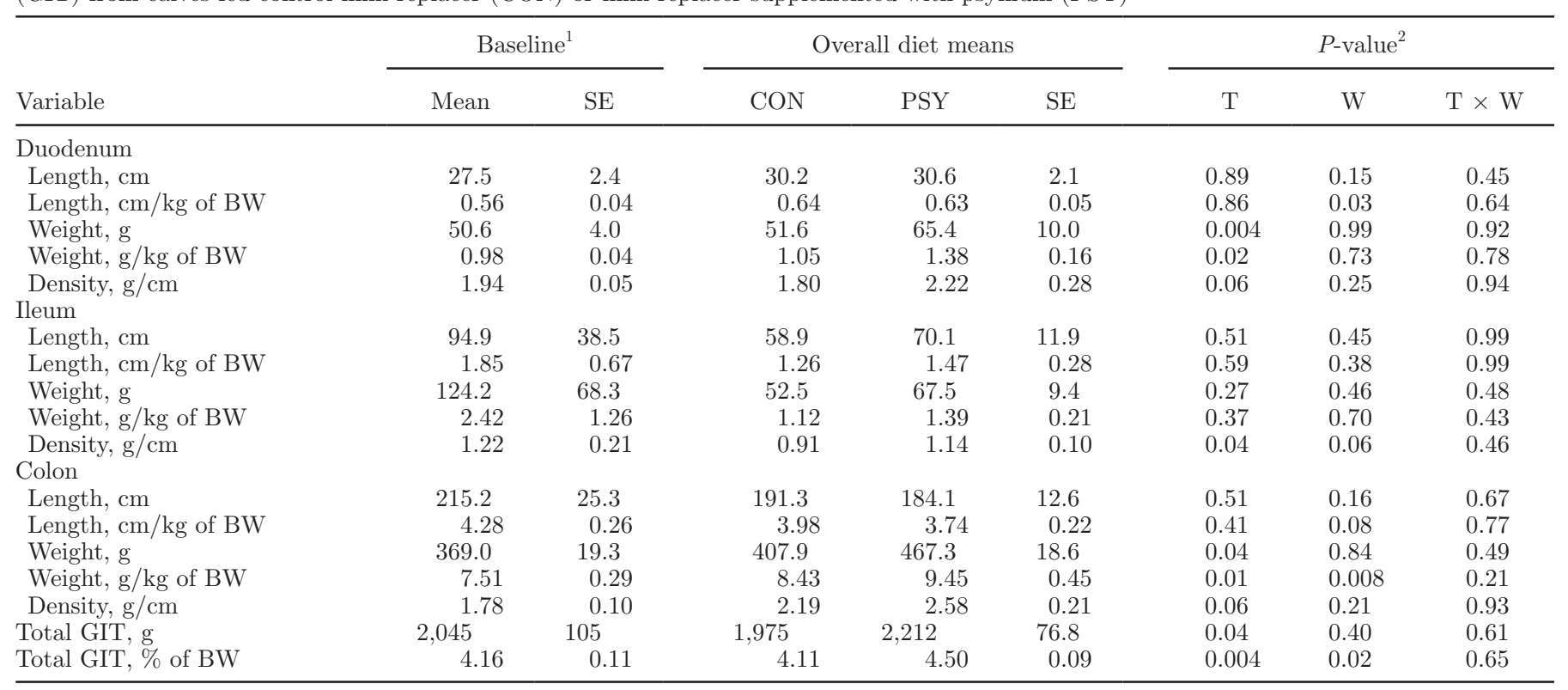

${ }^{1}$ Baseline values are shown for informational purposes and are not included in the statistical analyses.

${ }^{2} \mathrm{~T}=$ effect of treatment, $\mathrm{W}=$ effect of week, $\mathrm{T} \times \mathrm{W}=$ treatment $\times$ week interaction.

or lactobacilli in the lower GIT despite the increase in VFA could be due to subtle differences in counts or to greater variation compared with other assays utilized in this study. On the other hand, the existing microbial population may have had the capacity to ferment the amount of added psyllium without causing any detectable shifts in the major genera of commensal bacteria. Addition of psyllium to milk replacer may also provide substrate for probiotic cultures in the digestive tract, which might overcome the limiting substrate availability for growth of probiotic species in calves fed all-milk protein milk replacers.

\section{ACKNOWLEDGMENTS}

The authors gratefully acknowledge the dedicated assistance of the graduate and undergraduate students in the Drackley laboratory (D. Carlson, N. Litherland, N. Janovick, J. McFadden, J. Stamey, D. Rincker, E. French, and B. Benefield).

\section{REFERENCES}

Anderson, K. L., T. G. Nagaraja, and J. L. Morrill. 1987a. Ruminal metabolic development in calves weaned conventionally or early. J. Dairy Sci. 70:1000-1005.

Anderson, K. L., T. G. Nagaraja, J. L. Morrill, T. B. Avery, S. J. Galitzer, and J. E. Boyer. 1987b. Ruminal microbial development in conventionally or early weaned calves. J. Anim. Sci. 64:12151226 .
Bryant, M. P., and L. A. Burkey. 1953. Cultural methods and some characteristics of some of the more numerous groups of bacteria in the bovine rumen. J. Dairy Sci. 36:205-217.

Campbell, J. M., and G. C. Fahey Jr.. 1997. Psyllium and methylcellulose fermentation properties in relation to insoluble and soluble fiber standards. Nutr. Res. 17:619-629.

Cannon, S. J., G. C. Fahey Jr., M. R. Murphy, C. L. Dikeman, B. L. Miller, and J. K. Drackley. 2010. Inclusion of psyllium in milk replacer for neonatal calves. 1. Effects on growth, digesta viscosity, rate of passage, nutrient digestibilities, and metabolites in blood. J. Dairy Sci. 93:3652-3660.

Cebra, M. L., F. B. Garry, C. K. Cebra, R. Adams, J. P. McCann, and M. Fettman. 1998. Treatment of neonatal calf diarrhea with an oral electrolyte solution supplemented with psyllium mucilloid. J. Vet. Intern. Med. 12:449-455.

Correa-Matos, N. J., S. M. Donovan, R. E. Isaacson, H. R. Gaskins, B. A. White, and K. A. Tappenden. 2003. Fermentable fiber reduces recovery time and improves intestinal function in piglets following Salmonella typhimurium infection. J. Nutr. 133:1845-1852.

Costa, M. A., T. Mehta, and J. R. Males. 1989a. Effect of dietary cellulose and psyllium husk on monkey colonic microbial metabolism in continuous culture. J. Nutr. 119:979-985.

Costa, M. A., T. Mehta, and J. R. Males. 1989b. Effects of dietary cellulose, psyllium husk, and cholesterol level on fecal and colonic microbial metabolism in monkeys. J. Nutr. 119:986-992.

Cummings, J. H., and G. T. Macfarlane. 2002. Gastrointestinal effects of prebiotics. Br. J. Nutr. 87(Suppl. 2):S145-S151.

Edwards, C. A., J. Bowen, W. G. Brydon, and M. A. Eastwood. 1992 The effects of ispaghula on rat caecal fermentation and stool output. Br. J. Nutr. 68:473-482.

Erwin, E. S., G. J. Marco, and E. M. Emery. 1961. Volatile fatty acid analysis of blood and rumen fluid by gas chromatography. J. Dairy Sci. 44:1768-1771.

FDA. 1992. Method \#196. Page 506 in Bacteriological Analytical Manual. 7th ed. Food and Drug Administration, Arlington, VA.

Gómez-Conde, M. S., J. García, S. Chamorro, P. Eiras, P. G. Rebollar, A. Pérez de Rozas, I. Badiola, C. de Blas, and R. Carabaño. 2007. 
Neutral detergent-soluble fiber improves gut barrier function in twenty-five-day-old weaned rabbits. J. Anim. Sci. 85:3313-3321.

Hayden, U. L., S. M. McGuirk, S. E. West, and H. V. Carey. 1998. Psyllium improves fecal consistency and prevents enhanced secretory responses in jejunal tissues of piglets infected with ETEC. Dig. Dis. Sci. 43:2536-2541.

Heinrichs, A. J. 2005. Rumen development in the dairy calf. Adv. Dairy Technol. 17:179-187.

Leng-Peschlow, E. 1991. Plantago ovata seeds as dietary fibre supplement: Physiological and metabolic effects in rats. Br. J. Nutr. $66: 331-349$.

Mälkki, A. 2001. Physical properties of dietary fiber as keys to physiological functions. Cereal Foods World 46:196-199.

Muñoa, F. J., and R. Pares. 1988. Selective medium for isolation and enumeration of Bifidobacterium spp. Appl. Environ. Microbiol. 54:1715-1718.

National Animal Health Monitoring System. 2007. Part 1: Reference of Dairy Cattle Health and Management Practices in the United States, 2007. USDA:APHIS:VS:CEAH, Ft. Collins, CO.

Naylor, J. M., and T. Liebel. 1995. Effect of psyllium on plasma concentration of glucose, breath hydrogen concentration, and fecal composition in calves with diarrhea treated orally with electrolyte solutions. Am. J. Vet. Res. 56:56-59.

Schneeman, B. O., and D. Richter. 1993. Changes in plasma and hepatic lipids, small intestinal histology and pancreatic enzyme activity due to aging and dietary fiber in rats. J. Nutr. 123:1328-1337.
Servin, A. L. 2004. Antagonistic activities of lactobacilli and bifidobacteria against microbial pathogens. FEMS Microbiol. Rev. 28:405-440.

Swanson, K. S., C. M. Grieshop, G. M. Clapper, R. G. Shields Jr. T. Belay, N. R. Merchen, and G. C. Fahey Jr.. 2001. Fruit and vegetable fiber fermentation by gut microflora from canines. J. Anim. Sci. 79:919-926.

Swanson, K. S., C. M. Grieshop, E. A. Flickinger, L. L. Bauer, H.-P. Healy, K. A. Dawson, N. R. Merchen, and G. C. Fahey Jr.. 2002. Supplemental fructooligosaccharides and mannanoligosaccharides influence immune function, ileal and total tract nutrient digestibilities, microbial populations and concentrations of protein catabolites in the large bowel of dogs. J. Nutr. 132:980-989.

Tappenden, K. A., D. M. Albin, A. L. Bartholome, and H. F. Mangian. 2003. Glucagon-like peptide-2 and short-chain fatty acids: A new twist to an old story. J. Nutr. 133:3717-3720.

Vlková, E., I. Trojanová, and V. Rada. 2006. Distribution of bifidobacteria in the gastrointestinal tract of calves. Folia Microbiol. (Praha) 51:325-328.

Yan, F., and D. B. Polk. 2004. Commensal bacteria in the gut: Learning who our friends are. Curr. Opin. Gastroenterol. 20:565-571.

Yu, L., H. Lutterodt, and Z. Cheng. 2009. Beneficial health properties of psyllium and approaches to improve its functionalities. Adv Food Nutr. Res. 55:193-220 